\title{
Turizm Destinasyonlarında Restoran Biçimleşmeleri: Kapadokya Bölgesi Üzerine Nitel Bir Araştırma*
}

Restaurant Configurations in Tourism Destinations: A Qualitative Study About Cappadocia

\author{
Gökhan YILMAZ*, Bahattin ÖZDEMiR** \\ *Arş. Gör., Akdeniz Üniversitesi, Turizm Fakültesi, Gastronomi ve Mutfak Sanatları Bölümü, 07058, Kampüs, Antalya. \\ E-posta: gokhanyilmaz@akdeniz.edu.tr \\ **Prof. Dr., Akdeniz Üniversitesi, Turizm Fakültesi, Gastronomi ve Mutfak Sanatları Bölümü, 07058, Kampüs, Antalya. \\ E-posta: bahattin@akdeniz.edu.tr
}

\section{MAKALE BILGILER}

Makale işlem bilgileri:

Gönderilme tarihi: 22 Mart 2016

Birinci düzeltme: 15 Temmuz 2016

İkinci düzeltme: 27 Eylül 2016

Kabul: 1 Ekim 2016

Anahtar sözcükler: Gastronomi, Restoran, Restoran biçimleşmeleri, Kapadokya.

\section{ARTICLE INFO}

Article history:

Submitted: 22 March 2016

Resubmitted: 15 July 2016

Resubmitted: 27 September 2016

Accepted: 1 October 2016

Key words: Gastronomy, Restaurant, Restaurant configurations, Cappadocia Region. öz

Arastırmada bir turizm destinasyonunda ortaya cıkabilecek restoran biçimlesmelerinin belirlenmesi ve bunda turist profili ve davranışının nası bir rol oynadığının anlaşııması amaçlanmaktadır. Araştırmanın alanı Kapadokya bölgesi olarak belirlenmiştir. Araştırmada nitel yaklaşım çerçevesinde veri toplama tekniği olarak doküman incelenmesi ile yarı yapılandırılmış görüșme gerçekleştirilmiș, veri analiz yöntemi olarak da içerik analizinden faydalanılmıştır. Görüşmeler bölgedeki 12 turizm paydaşı ile gerçekleştirilmiştir. Bulgular Kapadokya bölgesinde restoran biçimleşmelerinin otel restoranları, grup restoranları, butik restoranlar, etnik restoranlar ile kebap ve pide restoranları șeklinde olduğunu göstermektedir. Çalışmada restoran biçimleșmelerinde turizm türü ve turist davranışlarının etkilerine ilișkin bulgular da saptanmıștır.

\section{GíRiş}

Restoranlar, yiyecek hizmetleri endüstrisinin olduğu kadar turizm destinasyonlarının da önemli bir bileşenidir (Özdemir 2010). Turistler bölgeye özgü yiyecek ve içecekleri destinasyondaki yerel restoranlarda bulabilmektedir (Özdemir ve Çalışkan 2011). Restoranlar üzerine akademik çalışmaların tüketicilerin veya turistlerin restoran seçimi (Kivela 1997; Yüksel ve Yüksel 2002), enfor-

Bu makale, Gökhan YILMAZ'in Akdeniz Üniversitesi Sosyal Bilimler Enstitüsü'nde yazılan “Turizm Destinasyonlarında Restoran Biçimleşmeleri Üzerine Nitel Bir Araştırma: Kapadokya Örneği" başlıklı yüksek lisans tezinden derlenmiştir. masyon arayışı (Batra 2008), tatmini (Nam ve Lee 2011) ve davranışsal niyetleri (Kim ve Boo 2011) gibi konular üzerine odaklandığı dikkat çekmektedir. Turizm bağlamında restoran uygulamalarını inceleyen çalışmalarda ise daha çok restoranlarda şeflerin yerel yiyecek kullanımını etkileyen faktörlerin (Sharma vd. 2014; Özdemir vd. 2015) incelendiği görülmektedir. Ancak turizm destinasyonlarında restoranların hangi biçimlerde ortaya çıktı̆̆ına ilişkin nicel bir araştırmaya rastlanamamaktadir.

Restoranlarla ilgili ana akım yazına bakıld1ğında farklı restoran türlerini tanımlamak üzere sınıflandırmalar önerildiği görülmektedir. Bu 
bağlamda en genel hali ile restoranların da içinde yer aldığ 1 yiyecek hizmetleri endüstrisi, ticari yiyecek içecek işletmeleri ve ticari olmayan yiyecek içecek işletmeleri şeklinde ikiye ayrılmaktadır (Edwards ve Overstreet 2009). Restoran işletmeleri de ticari yiyecek içecek işletmeleri içerisinde yer almaktadır (Çalışkan ve Özdemir 2011). Diğer taraftan restoranların hizmet anlayışı, atmosfer, menü ve işgörenler gibi niteliklere bağlı olarak birbirinden farklılık gösterebileceği bilinmektedir (Dahmer ve Kahl 2009; Bujisic vd. 2014). Söz gelimi, Amerika Ulusal Restoran Birliği restoranları hızlı servis sunan, geleneksel, temalı, lüks ve diğer restoranlar olmak üzere beş kategoriye ayırmaktadır. Kılınç ve Çavuş (2010) ise restoranları sahiplik durumuna, ölçeklerine ve özelliklerine göre sinıflandırmaktadır. Restoranlar sahiplik durumuna göre bağımsız ve zincir restoranlar; ölçeklerine göre büyük, orta ve küçük restoranlar ve özelliklerine göre de menü seçimi, restoran düzenlemeleri ve konum dikkate alınarak lüks restoranlar, temalı restoranlar, etnik restoranlar, hizlı yemek sunan restoranlar şeklinde ayrılmaktadır. Ancak ilgili alanyazında masa servisi sunan restoranlar ile hizlı servis sunan restoranlar ayrımı daha yaygın bir şekilde yapılmaktadır (Kim ve Geistfeld 2003). Söz gelimi, Ottenbacher ve Harrington (2009) hizlı servis sunan restoranların kisıtlı bir menüsünün olmaS1, kısıtlı bir servis vermesi ve fiyatının düşük olması gibi özellikleri ile masa servisi sunan restoranlardan ayrıldığından bahsetmektedir. Turizm bağlamında ise destinasyonlarda hangi restoran türlerinin olduğuna ilişkin sadece Cohen ve Avieli (2004) tarafından kavramsal olarak destinasyonlardaki restoranların yerel restoranlar ve turizme yönelmiş restoranlar şeklinde iki ana türde incelendiği görülmektedir. Böylece ilgili yazında görgül bulgularına rastlanılmayan restoran biçimleşmelerinin bir destinasyonda ortaya çıkıp çıkmadığının incelenmesinin gerekliliği ortaya çıkmaktadır. Tüm bunların ışığında araştırmanın amacı bir turizm destinasyonunda ne tür restoran biçimleşmelerinin ortaya çıkabileceğini belirlemek ve destinasyonda farklı restoran biçimleşmelerinin ortaya çımasında turizmin nasıl bir rol oynadığını anlayabilmektir.

Çalışmada restoran türü yerine restoran biçim- leşmesi kavramının kullanılmasının daha uygun olacağı düşünülmektedir. Bunun birinci nedeni restoran biçimleşmesi kavramının bir sonuç yerine bir süreci ifade etmesidir. Belirli bir zaman diliminde başlıca restoran niteliklerinin belirli bir örüntü gösterecek şekilde bir araya gelmesi ile bir restoran biçimi ortaya çıkabilir ve bu sürece biçimleşme denebilir. Böylece restoran niteliklerinin farklılaşmasına bağlı olarak farklı restoran biçimlerinin ortaya çıkabileceğine vurgu yapılabilmektedir. İkinci neden ise kisa vadede birden fazla restoran biçiminin bir arada görülebilmesi ve bu durumun restoran türü kavramı ile anlattlamamasıdir.

\section{ALANYAZIN TARAMASI}

Bu bölümde, çalışmanın kavramsal çerçevesi ile Kapadokya bölgesindeki turizm hareketlerine değinilmektedir.

\section{Kavramsal Çerçeve}

Restoranlarda tüketici davranışları ile gastronomi ve turizm ilişkisini inceleyen araştırmaların oluşturduğu alanyazın, turizm destinasyonlarındaki restoran biçimleşmelerinin gerçekleştiği bağlamı anlamaya yardımcı olacak bir kavramsal çerçeve sunmaktadır. İlk olarak bir destinasyonda restoranların biçimleşmesinde turist profili ve davranışının önemli bir rol oynadığı düşünülebilir. Alanyazında birçok çalışma turist profilinin sosyodemografik unsurlar ve seyahat davranışları olmak üzere iki boyuttan oluştuğunu belirtmektedir (Özdemir vd. 2012b). Turist profili destinasyonda egemen bir turizm türünü ortaya çıkarabilmektedir. Süreç olarak bakıldığında belirli bir profil ve seyahat davranışı sergileyen ve destinasyona sürekli gelen turist grupları o destinasyonda bir turizm türünün yerleşmesine ve dolayısıyla egemen kılınmasına yol açmaktadır. Diğer taraftan bir destinasyonda belirli bir turizm türü egemen hale gelmişse bu turizm türünü talep eden ve belirli bir profil ve seyahat davranışı sergileyen turistler de o destinasyona gelmeye devam etmektedir. Her şey dahil paket turların da etkisiyle Antalya ve Alanya'da deniz-kum-güneş çekicilikleri üzerine egemen bir turizm türünün şekillenmiş olması (Çizel vd. 
2013) bu sürece örnek olarak gösterilebilir. Bu destinasyonları ziyaret eden turistlerin büyük bir kısmı (\%85'ten fazlası) seyahat aracilarından (tur operatörleri ve seyahat acentaları) her şey dahil paket tur satın alarak bölgeyi deniz-kum-güneş çekicilikleri ve tatil amaciyla ziyaret eden ailelerden oluşmaktadır (Özdemir vd. 2012a). Böylece bu destinasyonlarda kitle turizminin egemen olduğu bir turizm anlayışı ile belirli bir turist profili birbirini destekleyerek destinasyonları şekillendirmektedir. Bu tür destinasyonları ziyaret eden turistlerin çoğunun yerel yiyecek ve yerel restoranlara çok fazla ilgi göstermediği de görülmektedir (Boyne vd. 2003; Hjalager 2004). Diğer taraftan seyahatleri sırasında yemeği ve yerel gastronomiyi turizm deneyiminin önemli bir parçası ve hatta birincil deneyim olarak görebilen turistler olduğu (Quan ve Wang 2004; Mkono vd. 2013) ve bu turistlerin yerel yemekleri tüketme motivasyonlarının çok güçlü olabileceği (Fields 2002; Mak vd. 2012), dolayısıyla seyahatteyken yemek yemeyi destinasyonun kültürünü öğrenme fırsatı ve gündelik rutinlerinin zıttı olarak gören ve yerel yiyeceklerle ilgili aktif enformasyon arayışında olan turist tipolojilerinin varlığ 1 (Boyne vd. 2003; Hjalager 2004) bilinmektedir. Böylece destinasyonlarda farklı restoran biçimlerinin belirmesine yol açabilecek farklı turist davranışlarının olabileceği anlaşılmaktadır. Üner (2014) tarafından yapılan çalışma bu görüşleri destekler nitelikte bulgular sunmaktadır. Antalya'yı ziyaret eden Alman ve Rus ağırlıklı 264 turistle yapılan çalışmada turistlerin seyahatleri esnasında yemek yediği restoranlar otel restoranları $(\% 67,2)$, yerel ürünler sunan restoranlar $(\% 19,6)$, uluslararası ürünler sunan restoranlar $(\% 8,8)$, zincir restoranlar $(\% 2,4)$ ve diğer $(\% 2)$ şeklinde sıralanmaktadır. Buna göre turistler bir destinasyonda farklı türlerdeki restoranları ziyaret etmeyi tercih edebilmektedir. Bu tercihlerde destinasyonlarda farklı restoran biçimleşmelerinin kaynağı olabilir.

Alanyazına göre restoran niteliklerinin de restoran biçimleşmelerinde etkili olduğu söylenebilir. Bu nedenle restoran nitelikleri ile ilgili yapılan çalışmalara göz atmak gerekmektedir. Restoran seçimini etkileyen faktörler üzerine yapılmış araştırmalarda yiyeceğin kalitesi, çeşitliliği, lez- zeti, sunumu, porsiyon miktarı ve fiyatı; restoranın atmosferi, dekoru, temizliği, çalışma saatleri, ünü ve konumu; personelin tutumu ve davranışları, hizmet kalitesi, servis hızı gibi niteliklerin öne çıktığı görülmektedir (Choi ve Zhao 2010). Restoranlardaki yemek deneyimi ile ilgili çalışmalara göre ise yemek deneyimi restoranın iç tasarımı, sosyal karşılaşma, yiyecek ve içecekler, atmosfer, eşlik edilme, servis, ödeme ve yönetim kontrol sistemi gibi bileşenlerden oluşmaktadir (Andersson ve Mossberg 2004; Gustafsson 2004). Restoranlarda tatmin konusunda yapilan araştırmalarda ise yiyecek, hizmet, servis personeli ve atmosfer gibi faktörlerin müşteri memnuniyetini etkilediği belirtilmektedir (Han ve Ryu 2009; Nam ve Lee 2011). Restoranlarda tüketici davranışları ile ilgili araştırmaların bulguları seçim, deneyim ve tatmin gibi alanlarda birbirine benzerlik gösteren çok sayıda niteliğin etkili olduğunu göstermektedir. Bu nitelikleri menü, atmosfer, konum ve işgörenler olmak üzere başlıca faktörler altında düşünmek mümkündür. Restoran biçimleşmelerin ortaya çıkmasında bu faktörlerdeki farklılaşmaların etkili olabileceği söylenebilir.

Turizm anlayışı, turist davranışı ve restoran niteliklerindeki değişimlere bağlı olarak destinasyonlardaki restoranların bazılarının yerel kalabildikleri bazılarının ise turizme yönelebildikleri görülmektedir. Yerel kalan restoranların özellikle yerel halka hitap ettiği, turizme yönelmiş olan restoranların ise Cohen ve Avieli'nin de (2004) belirttiği gibi turistleri hedef kitle olarak seçtiği söylenebilir. Menü bağlamında yerel restoranlar yerel halkın ihtiyaçları çerçevesinde menülerini şekillendirebilmektedir. Turizme yönelmiş restoranlar ise turistlerin damak tatlarına göre sunulan yemek ve menü içeriklerini kullanabilmektedir. İnsan kaynağı açısından bakıldığında da benzer bir durum ortaya çıkabilmektedir. Turizme yönelmiş restoranlarda gelen turist profiline uygun bir biçimde turistlerin kendi milliyetinden işgörenlerin istihdam edilebileceği görülmektedir. Atmosfer açısından bakıldığında turizme yönelmiş restoranlarda yerel kültüre ait unsurları da turistlere sunarak bir farklilık yaratabilmek için otantik atmosfer gözlemlenebilmektedir. Yerel restoranlarda da atmosfer tamamen yerel un- 
surlardan oluşabilmektedir. Turizme yönelmiş restoranlar ile yerel restoranlar konum açısından karşılaştırıldığında turizme yönelmiş restoranlar genellikle turistlerin yoğun olduğu yerlerde veya turizm merkezlerinde konumlanmakta iken yerel restoranlar ise yerel halkın yaşadığı yerlerde bulunmaktadır. Ancak konuyu derinlemesine incelemeye olanak veren görgül bir araştırma ile destinasyonlarda turizme yönelmiş ve yerel restoran olmak üzere iki ana biçimleşme dışında da biçimleşmeler olabileceği saptanabilir.

\section{Kapadokya Bölgesi’nde Turizm}

Bu çalışmada araştırma alanı Kapadokya bölgesi olarak belirlenmiştir. Kapadokya doğal güzelliklere, tarihi zenginliklere ve kültürel çekiciliklere sahip bir turizm merkezi olarak görülmekte ve kültür ve inanç turizmi ile ön plana çıkmaktadır. Bölgede turizm hareketleri daha çok grup turlarından oluşmaktadır. Bu çerçevede seyahat acentaları bölgede yoğun bir şekilde günlük turlar düzenlemektedir (İlhan ve Ersoy 2011). Bu turlarda turistler doğal ve kültürel çekicilikleri ziyaret etmektedir. Ancak bu çekicilikler kısa süreler içerisinde gerçekleştirilen bu turlar ile gezildiği için turistlerin ortalama kalış süreleri de kısa olmakta ve genellikle iki günü geçmemektedir (Şahin 2013). Yılmaz ve Özdemir (2015) bölgeyi 2014 yılında yerli ve yabancı olmak üzere toplam iki milyon 586 bin 528 turistin ziyaret ettiğini belirtmektedir. Bölgede balon turizmi, atlı doğa turiz$\mathrm{mi}$, spor ve golf turizmi, eğlence turizmi, termal turizm, kongre turizmi, gastronomi turizmi ve şarap turizmi gibi alternatif turizm çeşitleri yapıldığı da görülmektedir. Ancak bunların bölgeye kültür ve inanç turizmi kapsamında gelen turistler için birer alt faaliyet olarak yapıldığı veya gastronomi ve şarap turizmi için söylenebileceği gibi çok az sayıda turistin katılımı ile çok az sıklıkta gerçekleştiği gözlemlenmektedir (Yılmaz ve Özdemir 2015).

Bölgede yerel gastronominin turizmle bütünleştirilmesi konusunda gelişmeler yaşandığına ilişkin de işaretler bulunmaktadır. Söz gelimi, Çağlı (2012) tarafından yapılan bir çalışmada bölgeye yönelik gastronomi turlarının düzenlendiği, gastronomi amaciyla bölgenin ziyaret edildiği ve bölgenin hem şarap hem de gastronomi meraklılarını çektiği sonucuna varılmıştır. Şahin (2013) de bölgeye gelen turistlerin seyahatleri esnasında katıldıkları faaliyetler arasında yerel yemekleri deneyimlemenin $(\% 61,7)$ bulunduğunu ve şarap ile ilgili etkinliklere katılımın da $(\% 11,7)$ önemli bir faaliyet olduğunu belirtmektedir. Bölgede belirli bir egemen turizm türü (kültür turizmi) ve turizm yapılış biçiminin (paket turla bölgeye turist getirme ve bölgede günlük turlar düzenleme) olması; buna karşın şarap ve gastronomi turizmi gibi turizm türlerinin gelişmeye başlaması gibi nedenlerle Kapadokya'nın çalışmanın amacına uygun bir alan olduğu anlaşılmaktadır. Ayrıca araştırmacılardan birinin lisans eğitimini bölgede tamamlaması ve çalışmaya dahil edilebilecek potansiyel katılımcılarla iletişiminin olması da nedenler arasında yer almaktadır.

\section{YÖNTEM}

Araştırmada nitel araştırma yaklaşımından yararlanılmıştır. Böylece Kapadokya bölgesindeki turizm paydaşlarının görüşlerinin derinlemesine incelenebileceği ve restoran biçimleşmelerine ilişkin ayrıntılı verilere ulaşılabileceği düşünülmektedir. Araştırmanın deseni, iç içe geçmiş tek durum çalışması olarak belirlenmiştir. Nitel yaklaşım çerçevesinde veri toplama tekniği olarak doküman incelenmesi ile yarı yapılandırılmış görüşme; veri analiz yöntemi olarak da içerik analizinden yararlanılmıştır.

Araştırma yöntemi birbirini izleyen ve tamamlayan üç ana bileşenden oluşmaktadır. İlk iki bileşen Türkiye genelinde gastronomi ve turizm ilişkisine dair dokümanların incelenmesi ve Kapadokya bölgesinde gastronomi ve turizm ilişkisine dair dokümanların incelenmesi şeklinde s1ralanmaktadır. Üçüncü bileşen olarak iki aşamada toplanan veriler her bir aşamayı takiben içerik analize tabi tutulmuştur. Doküman incelemeleri ile toplanan verilerin analizi sonucu elde edilen bulgular görüşmeler esnasında sorulacak soruların belirlenmesi ve dolayısıyla yarı yapılandırılmış soru formunun oluşturulması için güvenilir bir zemin sağlamıştır. 


\section{Veri Toplama}

Gastronomi ve turizm ilişkisi üzerine doküman taraması 5-13 Haziran 2014 tarihleri arasında internet üzerinden yapılmıştır. Türleri açısından incelendiğinde taranan dokümanlar arasında haber, röportaj, makale ve demeç şeklinde sınıflandırılabilecek metinler yer almaktadır. Diğer taraftan dokümanlar konuyu ele aldıkları coğrafi düzeye göre (ulusal veya bölgesel) "Türkiye'de gastronomi ve turizm ilişkisi üzerine dokümanlar" ve "Kapadokya'da gastronomi ve turizm ilişkisi üzerine dokümanlar" olmak üzere iki gruba ayrılmıştır. Dokümanlarda bulunan kaynak kişiler arasında dernek ve birlik temsilcileri, acenta yetkilileri, restoran işletmecileri, gazeteci yazarlar, otel işletmecileri, şefler ve aşçılar, akademisyenler ve turist rehberleri gibi başlica turizm paydaşları yer almaktadır. Birinci grupta 38 adet ve ikinci grupta 21 adet olmak üzere toplamda 59 adet doküman incelemeye alınmıştır. Bu dokümanlara gastronomi ve turizm, gastronomi turizmi, yemek turizmi, Türkiye ve gastronomi, Kapadokya ve yerel mutfak, Kapadokya ve gastronomi turizmi gibi anahtar kelimeler kullanılarak erişilmiştir.

Araştırma kapsamında veri toplama amacıyla görüşme tekniği de kullanılmıştır. Görüşmelerin belirli bir ölçüde tutarlılık içerisinde gerçekleşmesine katkı vermek ve araştırma ile ilgili başl1ca konuları atlamamak için görüşmeler sırasında yarı yapılandırılmış görüşme formu kullanılmıştır. Soru formundaki olası sorular içerik analizi sonucu elde edilen doküman incelemesinin bulguları ve ilgili alanyazından yararlanılarak oluşturulmuştur. Hazırlanan olası görüşme soruları iki farklı araştırmacı tarafından tekrar incelenmiş ve ardından taslak şeklinde bir görüşme formu hazırlanmıştır. Hazırlanan taslak soru formu daha önce bölgede profesyonel turist rehberliği deneyimi olan ve halen üniversitelerin turizm rehberliği bölümlerinde öğretim üyesi olan üç uzmanın görüşüne sunulmuş ve önerileri doğrultusunda gerekli düzeltmeler yapılmıştır. Görüşme formu iki grup sorudan oluşmaktadır. Birinci grupta Kapadokya bölgesine gelen turist profilinin ortaya çıkarılması, turistlerin yerel mutfağa karşı ilgi ve katılım düzeyleri ile enformasyon kaynaklarının tespit edilmesi, bölgedeki restoran uygulamaları ile ilgili bilgi alınması, bölge turizminde gastronominin rolünün ortaya konulması ve gastronomi turizminin etkin bir şekilde kullanılması hakkında bilgi toplanmasını amaçlayan sorular yer almaktadır. İkinci grup sorular ise katılımcılara ilişkin demografik bilgileri elde etmeyi amaçlamaktadır.

\section{Örneklem}

Nitel araştırma yönteminde araştırmanın konusunu oluşturan olay ya da kişilerle ilgili derinlemesine bir inceleme yapabilmek için örneklem küçük tutulmakta ve rastgele örneklem seçimi yerine amaçlı örnekleme tercih edilmektedir (Miles ve Huberman 1994). Bu çalışmada amaçlı örnekleme yöntemi çerçevesinde azami çeşitlilik örneklemesi kullanılmıştır. Buna göre araştırmanın örneklemine dahil edileceklerin Kapadokya bölgesinde turizme yön veren paydaşlardan seçilmesine özen gösterilmiştir. Bu ölçütlere göre görüşme yapılacak olası kişiler belirlendikten sonra iletişim bilgileri kullanılarak her birine önce telefon aracılığıyla ulaşılmış ve kısa bir şekilde araştırmanın amacı ve içeriği ile araştırmacının kimliği açıklanmıştır. Araştırmaya katılmayı kabul eden katılımcılardan yüz yüze görüşme yapılabilmesi için randevu istenmiş ve randevu listesi oluşturulmuştur.

Görüşmelerin tamamı, gönüllülük esasına dayalı olarak araştırmacı tarafından gerçekleştirilmiş ve 21-26 Temmuz 2014 tarihleri arasında Kapadokya bölgesinde görüşmeler tamamlanmıştır. Katılımcılarla görev yaptıkları kurum, kuruluş veya işletmelerinde görüşme yapılmıştır. Bu bağlamda öğretim üyesi, öğretim elemanı, dernek başkanı, aşçıaşı, profesyonel turist rehberi, otel genel müdürü, seyahat acentası yetkilisi ve İl Kültür ve Turizm Müdürlüğü şube müdürü olmak üzere toplam 12 turizm paydaşı örnekleme dahil edilebilmiştir. Bu sayıdaki paydaşla yapılan görüşmelerle verilerin belirli bir doygunluğa ulaştığ 1 ve anlatıların tekrarlanmaya başladı ̆̆ı anlaşıldığından (Miles ve Huberman 1994) katılımcı sayısı yeterli görülmüştür. Görüşülen her paydaşa önce araştırmanın içeriği ve amacı hakkında bilgi verilmiş, gönüllü katılımcı bilgi- 
lendirme formunu doldurmaları istenmiş ve al1nan izin ile görüşmeler ses kayıt cihazı ile kayıt altına alınmıştır. Görüşme yapılan kişiler P1, P2, P3 şeklinde sıralanmış ve katılımcılara P1 ile P12 arasında kodlar verilmiştir. Görüşmelerin süresi 36 dakika ile 70 dakika arasında değişiklik göstermektedir. Görüşmelerin sürelerine bakıldığında ortalama 49 dakika ve toplamda 596,5 dakika olduğu görülmektedir. Görüşmelerde alınan ses kayıtları yazılı hale getirilmiş, ardından kayıtlar tekrar dinlenilerek yazılı metin ile karşılaştırılmış ve metinlerin doğrulaması yapılmıştır.

\section{Analiz}

Çalışmada, gerek dokümanlarda yer alan gerekse görüşmeler ile oluşturulan metinlerin analizi için içerik analizinden yararlanılmıştır. Analize başlamadan önce analiz biriminin belirlenmesi ve tümevarım ya da tümdengelim yaklaşımlarından birinin benimsenmesi gerekmektedir (Braun ve Clarke 2006). Bu bağlamda bu çalışmada doküman incelemesi için ulaşılan her bir doküman ve görüşmeler için de görüşülen her bir katılımcıya ait görüşme metni analiz birimi olarak seçilmiştir. İncelenen olgu ile ilgili gelişmiş bir kuramsal altyapının olması durumunda tümdengelim yaklaşımı benimsenirken aksi durumda ise tümevarım yaklaşımı önerilmektedir (Hsieh ve Shannon 2005). Bu çalışmada, turizm bağlamında restoran biçimleşmeleri ile ilgili bir kuramsal altyapının olmadığı da dikkate alınarak tümevarım yaklaşı$\mathrm{m}$ tercih edilmiştir. Bu kapsamda içerik analizinde Strauss ve Corbin (1990) tarafından önerilen modele uyulmuş ve kodlama, kategorileri belirleme, kategorileri isimlendirme ve kategorilere ilişkin özellikleri tanımlama işlemleri gerçekleştirilmiştir. Bu sürece uygun olarak önce metinlerin araştırmacılar tarafından ön okuması yapılmış ve daha sonra kod şemaları çıkarılmıştır. Belirlenen kod şemalarına göre dokümanlar ve görüşme metinleri iki farklı araştırmacı tarafından incelenmiş ve kodlamalar yapılmıştır. Ardından kodlamalar karşılaştırılmış, birbirine benzerlik gösteren ve göstermeyen hususlar tespit edilmiştir. Kodlama sürecini takiben kategorilerin oluşturulması aşamasına geçilmiş ve birbiri ile benzerlik gösteren alt kategoriler bir araya getirilerek ana kategoriler oluşturulmuştur. Bu aşamada da iki araştırmacı arasında kategorilerin oluşumu ve isimlendirilmesi konularında uzlaşılarak tartı̧̧malar sonlandırılmıştır.

Yukarıda anlatılan sürece uygun olarak gastronomi ve turizm ilişkisi üzerine dokümanların (Türkiye ve Kapadokya ile ilgili) analizi için doküman taraması sonucu elde edilen dokümanların araştırmacılar tarafından okumaları yapılmış ve bir kod şeması ortaya çıkarılmıştır. Belirlenen kod şemasına göre dokümanlar 30 Haziran - 8 Temmuz 2014 tarihleri arasında iki farklı araştırmacı tarafından incelenmiş ve kodlamalar yapılmış, kategoriler ve alıntılar belirlenmiştir. Ardından bir araştırmacı eşliğinde iki farklı araştırmacı tarafından yapılan kodlamalar karşılaştırılmış, birbirine benzerlik gösteren ve göstermeyen hususlar tespit edilmiştir.

Görüşmeler ile elde edilen metinlerin analizi için doküman taraması ve ilgili yazından da yararlanılarak bir kod şeması geliştirilmiştir. Ardından 13-18 Ağustos 2014 tarihleri arasında iki farklı araştırmacı kod şemasına göre metinleri tekrar okumuş ve kodlama yapmıştır. İki farklı araştırmacı tarafından yapılan bu işlem sonrasında elde edilen sonuçlar karşılaştırılmış ve tartışılmıştır. Kodlara ilişkin farklılıklar ve tartışmalar bitene kadar bu süreç devam etmiş ve sonunda bir anlaşmaya varılmıştır. Kodlama sürecinin ardından kategorilerin oluşturulması aşamasına geçilmiştir. Bu aşama sonrasında da iki araştırmacı arasında kategorilerin oluşumu ve isimlendirilmesi konularında uzlaşılarak tartışmalar sonlandırılmıştır.

\section{İnandırıcilık}

Nitel araştırmalarda çalışmanın inandırıcılığı, önemli bir husustur (Yıldırım ve Şimşek 2013). İnandırıcılığı sağlamanın ve göstermenin ise araştırmacının kendisinin veri toplama aşamasına dahil olması (Kozak 2014); araştırma ve veri analiz süreci ile ilgili detaylı bilgi verilmesi, analiz edilen metinden doğrudan alıntılar sunulması, kod şeması kullanarak kodlama yapılması (Elo vd. 2014) kodlamanın en az iki farklı kodlayıcı tarafından yapılması (Hall ve Valentin 2005) ve araştırmacılar arasında kod şemasının geliştirilmesi, kod şemasının metne uygulanması 
ve kategorilerin belirlenmesi sürecinde tartışmaların yapılması (Graneheim ve Lundman 2004) gibi yolları bulunmaktadır. Bu çalışmada da bu hususların hepsine dikkat edilmiştir. Bu kapsamda araştırma yöntemine ilişkin olabildiğince ayrıntılı bilgiler verilmiş; bulguların sunumunda metinlerde yer alan ifadelerden doğrudan alıntılar sunulmuş; içerik analizinde öncelikle bir kod şeması geliştirilmiş ve ardından iki farklı araştırmacı tarafından kod şemaları kullanılarak kodlama ayrı ayrı yapılmış ve analizin her aşamasında araştırmacılar arası tartışmalar ve uzlaşı arayışı gerçekleştirilmiştir. Bunlara ek olarak paydaşlardan araştırmanın bulguları ile ilgili görüşlerinin alınması da inandırıcılığı arttırmaktadır. Bu bağlamda analizler sonrasında Kapadokya bölgesinde faaliyet gösteren 12 restoran sahibi, müdürü veya işletmecisine ulaşılarak çalışma sürecinde elde edilen bulgular kendilerine anlatılmış, görüş ve fikirleri alınmıştır. Bu süreç sonunda görüşü alınan restoran yöneticileri bulguların bölge için doğruluğunu ifade etmiş ve kendi gerçekliklerini yansıttığını belirtmiştir.

\section{BULGULAR VE TARTIŞMA}

Bulgular bölümünde önce ön çalışmayı teşkil eden doküman incelemelerine ilişkin bulgulara kısaca yer verilmektedir. Ardından görüşmelere ilişkin bulgular daha kapsamlı ele alınmaktadır. Doküman incelemesi bulgularına göre
Türkiye'de gastronomi ve turizm ilişkisinin geliştirilmesi ve etkin bir şekilde sürdürülmesi için turizm paydaşları arasında güçlü bir desteğin var olduğu söylenebilir. Kapadokya bölgesi ile ilgili olarak da yerel gastronominin öneminin paydaşlar arasında kavranmış olduğu; bu konuda ilk adımların atılmaya başladığı ancak yolun çok başında olunduğu; tanıtım açısından henüz gastronomiye beklenen değerin verilmediği şeklinde bulgular ortaya çıkmıştır.

Görüşme yapılan katılımcılara ilişkin demografik bilgiler Tablo 1'de yer almaktadır. Katılımcıların yaşlarının 26 ile 60 arasında değiştiği ve profesyonel turist rehberi, seyahat acentası yetkilisi, İl Kültür ve Turizm Müdürlüğü şube müdürü, öğretim üyesi ve elemanı, aşçıbaşı, dernek başkanı, yönetim kurulu üyesi gibi çeşitli görevlerde bulunduğu görülmektedir. Katılımcıların toplam çalışma süresinin beş ile 38 yıl arasında değiştiği ve bölgede çalışma süresinin de 0,5 ile 38 yıl arasında olduğu dikkat çekmektedir.

Görüşmeler yolu ile elde edilen verilerin içerik analizine tabi tutulması sonucu elde edilen bulgular Tablo 2'de sunulmaktadır. Buna göre Kapadokya bölgesindeki restoran biçimleşmelerinin kavramsal yapısının dört adet ana kategori ile on dokuz alt kategoriden oluştuğu görülmektedir. İlk ana kategori bölgeyi ziyaret eden turistlerin profili ve davranışları ile ilgilidir ve bunun içerisinde milliyet çeşitliliği (bölgenin çok sayıda

Tablo 1. Katılımcılara İlişkin Demografik Bilgiler

\begin{tabular}{|c|c|c|c|c|c|}
\hline Katilımcı & Yaş & Eğitim & Meslek & Toplam Çalışma Süresi & Bölgedeki Çalışma Süresi \\
\hline P1 & 50 & Lisans & Seyahat Acentası Yetkilisi- Rehber & 25 & 20 \\
\hline P2 & 36 & Lise & Dernek Başkanı- Aşçıbaşı & 25 & 25 \\
\hline P3 & 26 & Lisans & Profesyonel Turist Rehberi & 9 & 6 \\
\hline P4 & 51 & Lisans & Halkbilimci- Şube Müdürü & 27 & 25 \\
\hline P5 & 51 & Doktora & Öğretim Üyesi & 30 & 24 \\
\hline P6 & 47 & Doktora & Öğretim Üyesi & 22 & 22 \\
\hline P7 & 60 & Lisans & Profesyonel Turist Rehberi & 38 & 38 \\
\hline P8 & 48 & Lisans & Yönetim Kurulu Üyesi - 5* Otel Genel Müdürü & 30 & 24 \\
\hline P9 & 28 & Lisans & Profesyonel Turist Rehberi & 5 & 5 \\
\hline P10 & 38 & Lisans & Öğretim Elemanı- Aşçıbaşı & 12 & 6 \\
\hline P11 & 47 & Lise & Dernek Başkanı - Rehber & 28 & 18 \\
\hline P12 & 27 & Lisans & Öğretim Elemanı & 9 & 0.5 \\
\hline
\end{tabular}


ülkeden gelen turistler tarafından ziyaret edilmesi) katılımcıların sıklıkla vurguladığı bir husustur. Turistlerin bölgeyi daha çok kültürel ve doğal çekicilikleri deneyimleme motivasyonları ile ziyaret ettiği anlaşılmaktadır. Seyahat şekli olarak bakıldığında turistlerin bölgeye paket tur kapsaminda veya bireysel olarak geldikleri görülmektedir. Ağırlıklı olarak ise paket tur kapsamında bölgenin ziyaret edildiği saptanmıştır. Bu durum bölgede yapılan önceki çalışmaların (İlhan ve Ersoy 2011; Şahin 2013; Aslan vd. 2014; Yıldız ve Kılıç 2016) bulguları ile örtüşmektedir. Öte yandan bulgular bölgeye gelen turistlerin seyahat şeklinin konaklama türünü de etkilediğini göstermektedir. Bu bağlamda paket turla gelen turistler yıldızlı otellerde konaklama yaparken bireysel olarak gelenler ise butik otellerde konaklama yapmayı tercih etmektedir. Bölgede kalış süresinin nispeten kısa olduğu bilinmektedir. Bölgeye gelen turistlerin seyahat şekline göre ka- lış sürelerinin değiştiği de görülmektedir. Genellikle paket turla gelen turistler ortalama iki gece civarında kalmaktadır. Bireysel olarak seyahat edenlerde ise bu süre üç geceye çıkabilmektedir. Bölgeye gelen turistlerin bölgede yaptıkları ortalama harcama miktarı paket turla veya bireysel olarak geliş şekline göre değişmektedir. Bunun yanında internet üzerinden satın alma davranışı çoğunlukla bireysel olarak bölgeye gelen turistlerde görülmektedir.

Ana kategorilerin ikincisini egemen turizm anlayışı oluşturmaktadır. Buna göre bölgede sıklıkla günlük turlar düzenlenmektedir. Acentalar tarafından düzenlenen bu turlarda ziyaret edilen yerler önceden belirlenmekte ve değiştirilmemektedir. Bu bağlamda öğle yemeğine ayrılan süre kısa olmakta ve turistlerin damak tadına uygun olduğu düşünülen açı büfe restoranlar tercih edilmektedir. Bulgular seyahat acentalarının

Tablo 2. Görüşmeler ile İlgili Bulgular

\begin{tabular}{|c|c|c|}
\hline $\begin{array}{l}\text { Ana } \\
\text { Kategori }\end{array}$ & $\begin{array}{l}\text { Alt } \\
\text { Kategori }\end{array}$ & Örnek Alıntılar \\
\hline & Milliyet Çeşitliliği & $\begin{array}{l}\text { “Ocak- Şubat- Mart aylarında genelde Uzakdoğu çalışırız. Genelde Uzakdoğu çalışıyoruz. } \\
\text { Yaz döneminde Rus ve Polonyalı geliyor. Temmuz'un ortasından Kasım’a kadar } \\
\text { Fransız, Alman, Belçika. Ama genelde Fransız ve Alman ağırlıktadır. İspanyol ve İtalyanları da } \\
\text { unutmayalım.”(P2) }\end{array}$ \\
\hline & Seyahat Motivasyonu & $\begin{array}{l}\text { "Bölgeye gelen turistler daha ziyade kültür turizmi dediğimiz bölgedeki Hıristiyanlık dönemine } \\
\text { ait tarihi izleri görmek adına bölgeye gelmekte. Bunun yanında doğal güzellikler olarak da peribacaları } \\
\text { bölgemizde doğal çekicilikleri oluşturmakta. Peribacalarını izlemeye gelen insan sayısı da } \\
\text { oldukça yoğundur."( P4) }\end{array}$ \\
\hline \multirow[t]{5}{*}{$\begin{array}{l}\text { Turist } \\
\text { Profili ve } \\
\text { Davranışı }\end{array}$} & Seyahat Şekli & $\begin{array}{l}\text { "İnsanlar kafasında çıkarken ben Kapadokya'ya gideyim iki gün kalayım diye bir şey yok. Adamlar } \\
10 \text { günlük Anadolu turu içinde onun bir ayağı olarak görüyor. ... Buraya paket turla geliniyor, } \\
\text { bireysel gelenler de var ama ağırlıklı dediğin zaman \%80-90 diye bir rakamla } \\
\text { söylenir paket tur." (P5) }\end{array}$ \\
\hline & Konaklama Türü & $\begin{array}{l}\text { "Genelde paket tur alan turistler yıldızlı otellerde kalıyorlar, kişi sayısı fazla olduğu için, butik } \\
\text { otellerde sayı az olduğundan. Bireysel gelen turistler genelde butik otellerde kalıyorlar." (P9) }\end{array}$ \\
\hline & Kalış Süresi & $\begin{array}{l}\text { "Turistlerin konaklama süreleri ciddi bir sıkıntımız. Hala değişmedi. Münferit hareketlerde bu } \\
\text { ortalama üç dört günü bulmakta, ama paket turlarla gelen, seyahat acentalarının programları ile } \\
\text { gelenler hala bölgede maksimum iki geceleme yapmaktadır." (P8) }\end{array}$ \\
\hline & Harcama Düzeyi & $\begin{array}{l}\text { "Dolayısıyla rakamsal boyuttan ziyade butik tesislerde kalan misafirlerin bölgeye bıraktıkları daha } \\
\text { fazla. Çünkü bireysel geziyorlar, bölgedeki bireysel işletmelerden hizmet alıyorlar, dolayısıyla bölgeye } \\
\text { daha fazla katkı sunuyor. Gruplar da ise bu işi organize eden İstanbul, Antalya ve Ege. Bunlar } \\
\text { paketledikleri için direk müşteriden parayı tahsil ediyorlar. Buralara çok cüzi miktarda konaklama } \\
\text { ve yeme içmede para bırakıyorlar." (P1) }\end{array}$ \\
\hline & Satın Alma Davranışı & $\begin{array}{l}\text { "Bireysel olarak gelenler internetten araştırma yaparlar ya da kendi ülkelerinde bir acentadan hizmet } \\
\text { satın alırlar. Ama ağırlıklı olarak şu an turizmin şekli de ona dönüyor internet üzerinden alırlar. } \\
\text { İnternetten otelleri araştırırlar, belli sitelerde otellerin kaç puan aldıklarına bakarlar, ona göre otel } \\
\text { seçimini yaparlar. Daha sonra da ya otelden ya da buradaki seyahat acentasından hizmet alırlar. } \\
\text { Balon turu ve normal Kapadokya rehberli gezileri satın alırlar." (P3) }\end{array}$ \\
\hline
\end{tabular}


Tablo 2. Görüşmeler ile İlgili Bulgular (Devam)

\begin{tabular}{|c|c|c|}
\hline $\begin{array}{l}\text { Ana } \\
\text { Kategori }\end{array}$ & $\begin{array}{l}\text { Alt } \\
\text { Kategori }\end{array}$ & Örnek Alıntilar \\
\hline & $\begin{array}{l}\text { Günlük Turlar } \\
\text { Düzenlenmesi }\end{array}$ & $\begin{array}{l}\text { "Bölgede aslında alternatif olarak birçok tur var. Başlangıçta klasik kültür turları dediğimiz birisi } \\
\text { Nevşehir Avanos-Ürgüp üçgeninde kalan peribacalarının bol olduğu bir destinasyon. Bir yeraltı } \\
\text { şehri, krater gölü, Ihlara Vadisi ve kervansarayları içine alan başka bir destinasyon. Bir diğeri ise } \\
\text { Roma kalıntıları, kaya oyma kiliseleri içerisine alan Soğanlı Vadisi istikameti var. Bunlar kültürel amaçlı } \\
\text { sürekli turların gittiği bölgeler. Özel ilgi turları var, yürüyüş (yarım gün 7-15 km) yapıyor, onun } \\
\text { akabinde kültürel faaliyet yapıyor. çanak çömlek, halı dokumayı görebiliyor, taş onyx, ata binebiliyor, } \\
\text { rafting yapma imkanını sunmuştuk. Kano yapabiliyor, bisiklet binebiliyor.” (P1) }\end{array}$ \\
\hline $\begin{array}{l}\text { Egemen } \\
\text { Turizm } \\
\text { Anlayışı }\end{array}$ & $\begin{array}{l}\text { Tur Programlarının } \\
\text { Kat Olması }\end{array}$ & $\begin{array}{l}\text { "Rehberler olarak bizim programımız acentalar tarafindan belirlenir. Acentaların anlaştikları yerler } \\
\text { vardır, şurada yemek yiyeceksin, şunlara gideceksin, şunları yapacaksın derler. Dolayısıyla ne kadar } \\
\text { siz bir rehber olarak yöresel tatları tattırayım deseniz de tattramıyorsunuz....." (P8) }\end{array}$ \\
\hline
\end{tabular}

Maliyet ve Satış Acentalar birazcık kazanç amaçı baktıkları için olaya zaten öğle yemekleri ağırlıklı olarak satılıyor.

Kaygısının Baskın Onlarda en ucuz öğle yemeklerini nereden alıyorsa oraya götürüyorlar. Gastronomi konusunda çok

Olması iddialı olmak istemiyorlar. Şaraptan da pek bir gelir elde etmedikleri için eklemiyorlar." (P3)

Enformasyon Arayışı Bölgeye gelmeden yerel yiyeceklerle ilgili araştırma yapanlar var. Nasıl yapanlar var. Gelip özellikle bazı yemekleri soranlar var. Onlarda ellerine verdikleri broşür, birkaç kitapçık, bunlarda yazılan restoranlar var, oraya gelip pide yemek bu da bizim yöresel yemeklerden bir tanesi, saç kavurma yemek, fasulye veya dolma yemek istiyorlar." (P10)

"Bizden özellikle bilgiyi yemeği yedikten sonra talep ediyorlar. Bunun içinde neler var, nasıl yapılıyor. Yemeden, o tadı almadan gerçekten onu algılayamıyorlar." (P1)

Yerel

ile İlişkili

“Özellikle Bat ülkelerinden gelenler yerel mutfağa müthiş ilgililer, ama Uzakdoğu'dan gelenlerde bir sıkınt var hala. Özellikle Hintli sıkınt var, Çinlilerde sıkınt var, Japonlarda sıkıntı var. Sebebi farklı bir damak tadına sahip Anadolu mutfağı ..." (P1)

"Almanlar gelir yöresel yemek yer, Fransızlar, Turist İtalyanlar vb. gelir yöresel yemekleri yer. Hintliler ve Koreliler hariç, bunlar kendi çorbasını da kendi Davranışları yanında getirir, yosununu da kendi yanında getirir." (P11)

Gastronomik Turizm "Çoğunluğu bu turistlerin yerel yani turistik restoranlarda değil de normal halkın yemek yediği

Ürünlerini Tüketme restoranlarda yemek yemek istiyorlar, onu tatmak istiyorlar. Bunun birçok nedeni var. Çünkü orada fiyat dengesi çok önemli. Oradaki yemeklerin daha ucuz olduğunu düşünüyorlar turistik restoranlardan. İçeriklerinin de daha düşük fiyatta olduğunu, aslında daha kaliteli olduğunu da düşünüyorlar. Genelde normal halk nerede yiyorsa biz orada yiyelim düşüncesi var." (P9)

\begin{tabular}{|c|c|c|}
\hline & Hedef Pazar & $\begin{array}{l}\text { "Bireysel bazda gezenlerin talepleri var. Hangi restoranda ne yiyebilirim diye araştırıyor. Yerel bir } \\
\text { şeyi tatmak istiyor. Yavaş yavaş butik otelleri restoran açmaya zorluyor. Çünkü dışarıdan böyle } \\
\text { bir hizmeti alamıyorlar. O zaman kendisi restoran açıyor, bu müşterinin talebine karşılık cevap } \\
\text { vermeye çalışıyorlar." (P1) }\end{array}$ \\
\hline & Maliyet Kaygısı & $\begin{array}{l}\text { "Yerel yiyeceklere yer veriliyor, nasıl veriliyor, bugün sizi yerel mutfağa götüreceğiz deyip götürüyorlar. } \\
\text { Öğle yemeğinde tur esnasında Göreme'de bir restorana götürüyorlar, bu restoran çömlek kebabı } \\
\text { diye sunuyor, beyaz et var kırmızı et olması gerekirken. Sezon başında anlaşma yapmış ve söz vermiş, } \\
\text { maliyeti kurtarmak adına yerel mutfağa benzeyen bir takım ürünler sunuyor." (P6) }\end{array}$ \\
\hline \multirow[t]{3}{*}{$\begin{array}{l}\text { Restoran } \\
\text { Uygulamaları } \\
\text { ve } \\
\text { Biçimleşmeleri }\end{array}$} & Uyarlanma & $\begin{array}{l}\text { "O ülkelerin lezzeti yönünde mesela Hintlilere özel baharatlı ve vejetaryen yemekleri çıkartabiliyorlar. } \\
\text { O sebeple güncelliyorlar. Milliyetlere göre bir hazırlık da var." (P1) } \\
\text { "Bölgede bir Hint restoranı var, aşçıları Hintli, Türk değil. Uzakdoğu restoranı var aşçıları } \\
\text { Uzakdoğulu." (P2) } \\
\text { "Uyarlıyorlar kendilerini. Menü olarak uyarlıyorlar. Çoğunluğunda İngilizce açıklama şeklinde var. } \\
\text { En azından içinde ne olduğu İngilizce açıklama şeklinde var. Haricen de Japon gruplar için menüler } \\
\text { Japonca yapılabiliyor. Ağırlıklı olarak İngilizce şeklinde var." (P3) }\end{array}$ \\
\hline & Otantik Atmosfer & $\begin{array}{l}\text { "Oyma mağaraların restorana çevrilmesi, eski Yunan evlerinin, taş evlerin içerisinde restoranların } \\
\text { olması, buralarda servis yapııması, yine bu evlerin içerisinde bölgede yapılan çanak çömleklerin } \\
\text { konulması, kilimlerin duvarlara asılması, Soğanlı bebeklerinin süs olarak kullanılması çok } \\
\text { şahane. Gruplara hizmet veren restoranların haricinde hemen hemen hepsi bu tür restoranlar. } \\
\text { 3/4'ü bu şekilde restoranlardır." (P3) }\end{array}$ \\
\hline & Yerel Sunum & $\begin{array}{l}\text { "İbrahimpaşa'da Babayan Restoran var, orada bir abimiz var lakabı bombacı, geçen yıl bizi bir yemeğe } \\
\text { davet etti, tamamen kendi inşa etmiş evi, çok güzel bir vadi üzerinde, yemeklerini tamamen annesi ile } \\
\text { eşi yapıyor, tamamen yöresel sunum. İşte bizim bu tür mekânlara ihtiyacımız var. Öyle bir mekân } \\
\text { yap ki kaya oyması her şeyi var, içeride diğer illerimizin veya Türk mutfağını kötülemek adına değil } \\
\text { bizim yöresel yemeklerimize sahip çıkmadığımızı gösteren bir örnek olduğu için söylüyorum.” (P2) }\end{array}$ \\
\hline
\end{tabular}


Tablo 2. Görüşmeler ile İlgili Bulgular (Devam)

\begin{tabular}{|c|c|c|}
\hline $\begin{array}{l}\text { Ana } \\
\text { Kategori }\end{array}$ & $\begin{array}{l}\text { Alt } \\
\text { Kategori }\end{array}$ & Örnek Alıntilar \\
\hline $\begin{array}{l}\text { Uygulamaları } \\
\text { ve } \\
\text { Bçimleşmeleri }\end{array}$ & $\begin{array}{l}\text { Restoran } \\
\text { Biçimleşmeleri }\end{array}$ & $\begin{array}{l}\text { "Gruplar genelde otelde yiyor. Gruplar bölgeye çok ucuz fiyatlara gelmeye başladı. Burada bizim } \\
\text { maliyetlerimiz çok önemli." (P2) } \\
\text { "Grup turu yaptığımda grup turlarında gittiğimiz restoranlar açık Restoran büfe restoranlar. Açık büfe } \\
\text { restoranlara çok lüks restoran umuduyla gittiler ve umduklarını } \\
\text { bulamadılar doğal olarak. Menüden şikâyet geldi. Kırmızı et yoktu şeklinde." (P3) } \\
\text { "Bunun yanı sıra butik anlamda gastronomi restoranları var. Gerçekten bunları hakkını yemeyelim. } \\
100 \text { işletme varsa bunların beşi hak ediyor. O beş tane yerel kültürü de yansıtyor, tasarımı da } \\
\text { yansı̈ıyor. Birkaç örnek var, çok azınlıkta." (P7) } \\
\text { "Göreme'de restorancılık gelişmiş durumda ama yöresel mutfak gelişmiş değil. Göreme'de Hint } \\
\text { restoranı var, Göreme'de Uzakdoğu restoranı var, Göreme'de Türk restoranı yok. Göreme'de } \\
\text { Kapadokya yemeklerini yapan restoran yok denecek kadar az. Bu restoranların açıma sebebi } \\
\text { şöyle. Açılan restoranlar acentanın kendi restoranı, kendi grubu, kendi müşterisi, kendi yemeği. } \\
\text { Olaya öyle bakalım." (P2) } \\
\text { "Şehir içinde dolaşırken çok güzel bir yöre halkından birinin yaptı̆ı̆ı yemekleri sunduğu bir restoran } \\
\text { var. Ama sadece buna biz gidiyoruz." (P12) }\end{array}$ \\
\hline
\end{tabular}

günlük tur programlarına dahil edilecek restoranları tercih ederken maliyet ve satış kaygısının baskısı altında olduklarına da işaret etmektedir.

Ana kategorilerinden üçüncüsünü yerel gastronomi ile ilişkili turist davranışları oluşturmaktadır. Bu ana kategori kapsamında bulunan kategoriler ise enformasyon arayışı, yerel mutfağ deneyimleme ve gastronomik turizm ürünlerini tüketme şeklinde sıralanmaktadır. Bölgeye gelen turistlerin az da olsa bir kısmı gelmeden önce kitap, broşür, internet gibi kaynaklardan yerel gastronomi ile ilgili araştırma yapmaktadır. Ancak büyük bir kısmı bölgeye geldikten sonra yerel gastronomi hakkında enformasyon arayışı içerisine girmektedir. Araştırma bulguları turistlerden bazılarının yerel mutfağı deneyimlemeye açık olduğunu, bazılarının ise bundan uzak durduğunu göstermektedir. Buna göre turistlerin yerel gastronomi ile ilgili motivasyonlarının ve enformasyon arayışlarının sınırlı olduğu dikkat çekmektedir. Bu durum önceki çalışmaların bulguları ile benzerlik göstermektedir. Söz gelimi Boyne vd. (2003) tarafından yerel yiyecek ve içeceklere ilgilerine göre yapılan turist sınıflandırmasında Tür 2 grubunda yer alan turistlerin de yerel gastronomi ile ilgili enformasyon arayışında olmadıkları ve sadece yerel yiyecekler ile karşılaştıkları zaman enformasyon arayışına girdikleri belirtilmektedir. Hjalger' in (2004) dörtlü turist sinıflandırmasında rekreasyonel ve taklitçi turistlerin de yerel gastronomi ile ilgili motivasyonlarının ve enformasyon arayışlarının kısıtlı olduğu söylenmektedir. Mevcut araştırmanın bulgularına göre yerel mutfağı deneyimleme davranışı turistlerin milliyetine göre farklılık gösterebilmektedir. Söz gelimi, Batılı turistler yerel mutfağı deneyimleme hususunda istekli iken Uzakdoğulu ve Hint turistlerin yerel mutfağ 1 deneyimleme hususunda istekli olmadığı anlaşılmaktadır. Daha önce yapılan çalışmaların bulguları da (Mitchell ve Hall 2003; Ignatov ve Smith 2006; Yun vd. 2011; Vujicic vd. 2013) kültürel mesafenin yüksek olarak algılandığı ülkelere yapılan seyahatlerde turistlerin yerel yiyecekleri tüketme motivasyonlarının düşük olduğuna işaret etmektedir. Mevcut çalışma kapsamı ve hacmi sinırlı kalmakla birlikte bölgede turistlere yerel restoranlarda yemek yeme, şarap tadımı, yemek festivalleri, yemek pişirme kursları, bağbozumu ve şarap festivali gibi gastronomik turizm ürünlerinin sunulduğunu ve daha çok bireysel olarak seyahat edenler olmak üzere bu ürünleri tüketen turistlerin olduğunu da göstermektedir.

Ana kategorilerinden sonuncusunu restoran uygulamaları ve biçimleşmeleri oluşturmaktadır. $\mathrm{Bu}$ ana kategori kapsaminda bulunan alt kategoriler ise hedef pazar, maliyet kaygısı, uyarlanma, otantik atmosfer, yerel sunum ve restoran biçimleşmeleri şeklinde sıralanmaktadır. Bölgede bulunan restoranlar hedef pazar olarak kendilerine yerel halkı, paket turla gelen ve günlük turlara katılan turistleri veya bireysel olarak seyahat 
eden turistleri seçebilmektedir. Diğer taraftan restoran işletmelerinin operasyonlarında maliyet kaygısını ciddi şekilde hissedebildikleri de görülmektedir. Bazı restoranların maliyeti öncelikli kılması ve bu bağlamda sunulan yerel yiyeceklerin içeriğinde değişikliğe gitmesi veya porsiyon miktarını düşürmesi bu duruma örnek teşkil etmektedir. Maliyet kaygısının ve turist davranışlarının da etkisiyle restoranların (özellikle turistlere hitap edenler) bazı nitelikleri açısından uyarlanabileceğine yönelik bulgular da elde edilmiştir. Bu bağlamda restoranlar turistlerin damak tadına göre menülerini oluşturabilmekte ve yemeklerde, serviste ve işgören seçiminde uyarlamaya gidebilmektedir. Öte yandan, bölgede bazı restoranlar uyarlanmanın aksine yerel sunumu tercih edebilmektedir. Bu çerçevede turistlerin gittikleri yerin yemek kültürünü deneyimlemek isteyecekleri düşüncesine dayanılarak yerel malzemeler kullanılmakta, yerel yemekler hazırlanmakta ve yerel şaraplar sunulmaktadır. Ayrıca yerel halktan çalışanlar tercih edilmekte veya yerel adetlere göre yiyecek ve içecek servisi yapılmaktadır. Bölgede özellikle turistlere yönelen restoranların hemen hepsinde otantik atmosferin öne çıkan bir uygulama olduğu anlaşılmaktadır. Bu çerçevede restoranlar kaya oyma veya bölgeye özgü sarı taşlardan yapılan mekânları tercih edebilmekte ve dekorasyonda halı, kilim, çanak ve çömlek gibi bölgeye özgü kültürel unsurları kullanabilmektedir. Bölgedeki restoranların bölgeye özgü unsurları kullanarak otantik bir atmosfer sunma çabasına ilişkin bulgular George (2001) ve Molz (2004) tarafından yapılan çalışmaların bulguları ile örtüşmektedir. Söz gelimi George (2001) Çin restoranlarında Çin kültürüne özgü unsurların (renkler, sofra takımları, üniformalar gibi) kullanılması ile müşterilerde otantik bir atmosfer algılamasının yaratıldığı sonucuna ulaşmıştır. Molz (2004) ise Amerika'da bulunan Tai restoranlarında otantikliğin sunulan yiyecekler aracılığıyla yaratıldığını saptamıştır.

Çalışmanın önemli bulgularından biri de bölgede çok sayıda restoran biçimleşmesinin var olduğudur. Bölgedeki restoran biçimleşmelerinin (i) paket turla seyahat edenlerin yemek yediği, yıldızlı oteller bünyesinde yer alan ve açık büfe servis sunan otel restoranları; (ii) grup halinde gerçekleştirilen günlük turlara katılanların yemek yediği ve acentalarla anlaşmalı olarak hizmet veren grup restoranlarl; (iii) bireysel olarak seyahat edenlerin yerel yemekleri tatmak için ziyaret ettiği bağımsız şekilde veya bir butik otel bünyesinde hizmet veren butik restoranlar; (iv) Uzakdoğu'dan ve Hindistan'dan gelen turistler için hizmet veren Japon, Kore, Hint restoranları gibi etnik restoranlar ve (v) yerel halkın yemek yediği ve menüsünde pide - kebap çeşitleri ya da dönerin ağırlıkta olduğu ve daha çok şehir merkezinde konumlanmış olan kebap ve pide restoranları şeklinde olduğu anlaşılmaktadır. Araştırma bulguları ile tanımlanan bu restoran biçimleşmeleri ise ilgili alanyazına önemli bir katkı olarak görülmektedir. Daha önce destinasyonlardaki restoranların biçimleşmelerine ilişkin yerel ve turizme yönelmiş şeklinde bir tanımlama (Cohen ve Avieli 2004) yapılmışken bu çalışma ile çok sayıda biçimleşme olabileceği ortaya konmuş olmaktadır.

\section{SONUÇ}

Araştırmanın amacı bir turizm destinasyonunda ne tür restoran biçimleşmelerinin ortaya çıkabileceğini belirlemek ve destinasyonda farklı restoran biçimleşmelerinin ortaya çıkmasında turist profili ve davranışının nasıl bir rol oynadığını anlayabilmektir. Bu bağlamda araştırma çerçevesinde doküman incelemesi ve yarı yapılandırılmış görüşmeler yapılmıştır. Doküman incelemesi olarak öncelikle Türkiye genelinde gastronomi ve turizm ilişkisine dair dokümanlar incelenmiş ve ardından Kapadokya bölgesi ile ilgili gastronomi ve turizm ilişkisine dair dokümanlar incelemeye alınmıştır. Son aşama olarak da bölgedeki paydaşlarla görüşmeler yapılmıştır.

Araştırma bulguları özellikle turist davranışı ve turizm türünün restoran uygulamalarını ve dolayısıyla restoran biçimleşmelerini etkileyebileceğini göstermiştir. Turist profili ve davranışı ile bölgedeki egemen turizm anlayışı turistlerin yerel gastronomi ile ilgili davranışlarının şekillenmesinde de rol oynamaktadır. İlk olarak turistlerin yerel gastronomi ile ilgili enformasyon arayışlarının sınırlı olduğu dikkat çekmektedir. Diğer taraftan turistlerin yerel mutfağı deneyim- 
lemeye açık olmaları ya da bundan uzak durmalarında milliyetlerinin etkisinin olduğu da anlaşılmaktadır. Dolayısıyla yerel gastronomik turizm ürünlerini tüketme davranışları da sınırlılık göstermektedir. Bölgedeki turizm anlayışı ve turist davranışına ilişkin çok sayıda faktörün oluşturduğu bağlamda restoran uygulamaları da seçilen hedef pazara ve maliyet kaygisının hissedilme düzeyine göre uyarlanma ya da yerel sunum uçlarından birine kaymakta veya bunların arasında kalmaktadır. Ancak her koşulda bölgedeki restoranların bölgeye özgü unsurları kullanarak otantik bir atmosfer sunma çabası içerisinde oldukları görülmektedir. Bu bağlamda menü, atmosfer, konum ve insan kaynağının uyarlanması veya yerel özellikler taşıması restoranları birbirinden farklılaştırabilmekte ve bir destinasyonda çok sayıda restoran biçimleşmesinin gözlemlenmesine yol açabilmektedir. Söz konusu restoran uygulamalarının da bölgede çok sayıda otel restoranları, grup restoranları, butik restoranlar, etnik restoranlar ve kebap ve pide restoranları gibi restoran biçimleşmelerinin ortaya çıkmasında önemli bir rol oynadığı görünmektedir.

Araştırmanın hem kavramsal hem de metodolojik açıdan ilgili alanyazına çeşitli katkılarının olduğu söylenebilir. Kavramsal açıdan bakıldığında çalışmanın en önemli katkılarını şu şekilde açıklamak mümkün olmaktadır. Bu araştırmada bir turizm destinasyonunda gözlemlenebilecek restoran biçimleşmelerinin alanyazında var olan restoran sinıflandırmalarından farklı olduğu anlaşılmaktadır. Bu farklılığın nedenini ise bir destinasyondaki restoran uygulamalarının o destinasyonu ziyaret eden turistlerin davranışı ve destinasyondaki egemen turizm türünün etkisi ile ortaya çıkabileceği ve bu uygulamaların farklı biçimleşmeleri de beraberinde getirebileceği şeklinde açıklamak mümkün olmaktadır. Araştırmanın ikinci önemli kavramsal katkısı araştırma ile restoran uygulamaları ve bunların ortaya çıkardığı restoran biçimleşmelerine ilişkin ayrıntılı tanımlamaların verilmesi ve bu tanımlamaların bir destinasyondaki turizm paydaşlarının gözünden sunulması şeklinde söylenebilir. Çalışmanın metodolojik katkısı ise Türkiye'de gastronomi ve turizm ilişkisi üzerine yapılan araştırmalar ara- sında yöntem açısından da bir yenilik oluşturmasıdır. Diğer bir ifade ile daha çok nicel araştırma yaklaşımı ile yapılan önceki çalışmalara karşın bu çalışmada doküman incelemesi ve görüşmeleri içeren ve verilerin içerik analizi çerçevesinde analize tabi tutulduğu bir nitel yaklaşımın benimsenmiş olması ve belirli bir destinasyondaki turizm paydaşlarının görüşlerinin bu yolla incelenmiş olması önemli bir metodolojik katkı olarak görülebilir. Bu çerçevede nitel yöntemin bir destinasyonda gastronomik turizm ürünlerinin biçimleşmesinde turist davranışı ve turizm anlayışı gibi unsurların rolünü anlamada kullanılabilecek bir yaklaşım olduğu da gösterilmiş olmaktadir.

Araştırma çerçevesinde destinasyon pazarlamacıları ve yöneticileri ile restoranlar için çeşitli öneriler getirmek de olanaklı olmaktadır. Bölgede restoranlarla ilgili tanıtım niteliği taşıyan bir rehber olmadığı görülmektedir. Turistlerin enformasyon arayışına yanıt vermek amacıyla bölgede bulunan restoranlara ilişkin restoranların isimleri, iletişim bilgileri, menü içerikleri, türleri gibi bilgilerin yer aldığı restoran rehberleri oluşturulabilir. Restoran rehberlerine temel teşkil edecek şekilde menü, atmosfer, insan kaynağı ve konum gibi nitelikler açısından restoranlara ilişkin bir sınıflandırma yapılabilir. Diğer yandan bölgede restoranlar ile ilgili bir örgütlenmenin olmadığ görülmektedir. Bölgedeki restoranların kalite ölçütlerini geliştirmek amacıyla bölgedeki paydaşlar arasında koordinasyon ve işbirliğini sağlayacak bir örgütlenmeye gidilebilir. Bu örgütlenmenin de yönlendirmesi ile bölgede var olan ve farklı biçimlerde ortaya çıkan restoranlar arasında ürün tedarikinde ve tanıtımında işbirliği yapılabilir. Böylece yerel yiyecek malzemelerinin daha fazla oranda kullanımının teşvik edilmesi de olanaklı olabilir. Diğer taraftan bölgede yerel yiyecekleri ve kültürü sunma çabası içerisinde olan butik restoranların açılmasına ve desteklenmesine yönelik çalışmalar yapılabilir.

Araştırmanın bir takım sınırlılıkları bulunmaktadır. Araştırmanın başlıca sınırlılığını kültür turizminin egemen olduğu Kapadokya bölgesinde yapılmış olması oluşturmaktadır. Bu bağlamda ileriki araştırmalar farklı turizm türlerinin egemen olduğu farklı destinasyonlarda yapılabilir. 
Söz gelimi, deniz-güneş-kum turizminin egemen olduğu Antalya bölgesinde bir araştırma gerçekleştirilebilir. Araştırma kapsamında nitel yaklaşım çerçevesinde veri toplama tekniği olarak doküman incelenmesi ile yarı yapılandırılmış görüşmeden yararlanılmıştır. İleriki araştırmalarda odak grup görüşmesi de doküman incelemesi ve görüşmelere ilave olarak kullanılabilir ya da nicel yaklaşım çerçevesinde genellemelere de olanak verecek şekilde anket yöntemi kullanılabilir. Araştırmada örneklem dahilinde çeşitli turizm paydaşları ile görüşmeler yapılmıştır. İleriki çalışmalarda farklı örneklemler üzerinde araştırmalar gerçekleştirilebilir. Söz gelimi, araştırma seyahat acentaları ve tur operatörleri ya da restoran işletmecilerinin bakış açısıyla özelleştirilerek ele alınabilir. Araştırmanın bölgede var olan gastronomik turizm ürünlerinden sadece restoranlar üzerinde gerçekleştirilmesi diğer bir sınırlılığ 1 oluşturmaktadır. Bu bağlamda ileride bölgede var olan diğer gastronomik turizm ürünleri temel alınarak da çalışmalar yapılabilir.

\section{KAYNAKÇA}

Andersson, T. D. ve Mossberg, L. (2004). The Dining Experience: Do Restaurants Satisfy Customer Needs?, Food Service Technology, 4: 171-177.

Aslan, Z., Güneren, E. ve Çoban, G. (2014). Destinasyon Markalaşma Sürecinde Yöresel Mutfağın Rolü: Nevşehir Örneği, Journal of Tourism and Gastronomy Studies, 2 (4): 3-13.

Batra, A. (2008). Foreign Tourists' Motivation and Information Source(s) Influencing Their Preference for Eating Out at Ethnic Restaurants in Bangkok, International Journal of Hospitality \& Tourism Administration, 9 (1): 1-17.

Boyne, S., Hall, D. ve Williams, F. (2003), Policy, Support and Promotion for Food Related Tourism Initiatives: A Marketing Approach to Regional Development, Journal of Travel and Tourism Marketing, 14 (3/4): 131-154.

Braun, V. ve Clarke, V. (2006). Qualitative Research in Psychology, Using Thematic Analysis in Psychology, 3: 77-101.

Bujisic, M., Hutchinson, J. ve Parsa, H. G. (2014). The Effects of Restaurant Quality Attributes on Customer Behavioral Intentions, International Journal of Contemporary Hospitality Management, 26 (8): 1270-1291.

Choi, J. ve Zhao, J. (2010). Factors Influencing Restaurant Selection in South Florida: Is Health Issue One of The Factors Influencing Consumers' Behaviour When Selecting Restaurant?, Journal of Foodservice Business Research, 13: 237-251.

Cohen, E. ve Avieli, N. (2004). Food in Tourism: Attraction and Impediment, Annals of Tourism Research, 31 (4): 755-778.
Çağll, I. B. (2012). Türkiye'de Yerel Kültürün Turizm Odak11 Kalkınmadaki Rolü: Gastronomi Turizmi Örneği. (Basılmamış Yüksek Lisans Tezi). İstanbul: İstanbul Teknik Üniversitesi Fen Bilimleri Enstitüsü Şehir ve Bölge Planlama Anabilim Dalı.

Çalışkan, O. ve Özdemir, B. (2011). Uluslararası Turizm İşletmeciliğinde Restoran Yönetimi. İçinde İ. Pırnar, O. İçöz ve O. Çulha (Editörler). Uluslararası Turizm İşletmeciliği. (ss.251-282). Ankara: Nobel Akademik Yayıncilık.

Çizel R., Çizel B., Sarvan E.F. ve Özdemir B. (2013). Emergence And Spread of All Inclusive System in Turkish Tourism Sector And Strategic Responses of Accommodation Firms, International Journal of Hospitality and Tourism Administration, 14 (4): 305-340.

Dahmer, S. J. ve Kahl, K. W. (2009). Restaurant Service: Basic. New Jersey: John Wiley \& Sons.

Edwards, J. S. ve Overstreet, K. (2009). What Is Food Service?, Journal of Foodservice, 20 (1): 1-3.

Elo, S., Kaariainen, M., Kanste, O., Pölkki, T., Utriainen, K. ve Kyngas, H. (2014). Qualitative Content Analysis: A Focus on Trustworthiness. Sage Open. 1-10. DOI: $10.1177 / 2158244014522633$.

Fields, K. (2002). Demand for the Gastronomy Tourism Product: Motivational Factors. İçinde A. M. Hjalager. ve G. Richards (Editörler). Tourism and Gastronomy. (ss.3650). Londra: Routledge.

George, R. T. (2001). Dining Chinese: A Consumer Subgroup Comparison, Journal of Restaurant \& Foodservice Marketing, 4 (2): 67-86.

Graneheim, U. H. ve Lundman, B. (2004). Qualitative Content Analysis in Nursing Research: Concepts, Procedures and Measures to Achieve Trustworthiness, Nurse Education Today, 24: 105-112.

Gustafsson, I. (2004). Culinary Arts and Meal Science - A New Scientific Research Discipline, Food Service Techno$\log y, 4$ (1): 9-20.

Hall, C. M. ve Valentin, A. (2005). Content Analysis. İçinde B. Ritchie, P. Burns ve C. Palmer (Editörler). Tourism Research Methods. (ss. 191-209). Cambridge: CAB International.

Han, H. ve Ryu, K. (2009). The Roles of the Physical Environment, Price Perception, and Customer Satisfaction in Determining Customer Loyalty in The Restaurant Industry, Journal of Hospitality \& Tourism Research, 33 (4): 487-510.

Hjalager, A. M. (2004). What Do Tourists Eat and Why? Towards A Sociology of Gastronomy and Tourism, Tourism, 52 (2): 195-201.

Hsieh, H. ve Shannon, S. E. (2005). Three Approaches to Qualitative Content Analysis, Qualitative Health Research, 15 (9): 1277-1288.

Ignatov, E. ve Smith, S. (2006). Segmenting Canadian Culinary Tourists, Current Issues in Tourism, 9 (3): 235-255.

İlhan, İ. ve Ersoy, E. (2011). Nevşehir Ekonomisinin Sektörel Analizi. I. Uluslararası Nevşehir Tarih ve Kültür Sempozyumu. Cilt 4. (ss. 153-193). Nevşehir: Nevşehir Üniversitesi. 
Kılınç, O. ve Çavuş, Ş. (2010). Yiyecek - İçecek Sektörüne Genel Bakış. İçinde M. Sarış̧ık, Ş. Çavuş ve K. Karamustafa (Editörler). Profesyonel Restoran Yönetimi: Illkeler, Uygulamalar ve Örnek Olaylar. (ss. 1-18). Ankara: Detay Yayıncilik.

Kim, J. ve Boo, S. (2011). Influencing Factors on Customers' Intention to Complain in a Franchise Restaurant, Journal of Hospitality Marketing \& Management, 20: 217-237.

Kim, E. J. ve Geistfeld, L. V. (2003). Consumers' Restaurant Choice Behavior and The Impact of Socio-Economic and Demographic Factors, Journal of Foodservice Business Research, 6 (1): 3-24.

Kivela, J. (1997). Restaurant Marketing: Selection and Segmentation in Hong Kong, International Journal of Contemporary Hospitality Management, 9 (3): 116-123.

Kozak, M. (2014). Bilimsel Araştırma: Tasarım, Yazım ve Yayım Teknikleri. Ankara: Detay Yayıncilı.

Mak, A. H., Lumbers, M., Eves, A. ve Chang, R. C. (2012). Factors Influencing Tourist Food Consumption, International Journal of Hospitality Management, 31: 928-936.

Mitchell, R. ve Hall, C. M. (2003). Consuming Tourists: Food Tourism Consumer Behaviour. İçinde C. M. Hall, L. Sharples, R. Mitchell, N. Macionis ve B. Cambourne (Editörler). Food Tourism Around The World: Development, Management and Markets. (ss.60-80). New York: Routledge.

Miles, B. M. ve Huberman, A. M. (1994). Qualitative Data Analysis: An Expanded Source Book. California: Sage Yayınları.

Mkono, M., Markwell, K. ve Wilson, E. (2013). Applying Quan and Wang's Structural Model of the Tourist Experience: A Zimbabwean Netnography of Food Tourism, Tourism Management Perspectives, 5: 68-74.

Molz, J. G. (2004). Tasting an Imagined Thailand: Authenticity and Culinary Tourism in Thai Restaurants. İçinde L. M. Long (Editör). Culinary Tourism. (ss. 53-75). Kentucky: The University Press of Kentucky.

Nam, J. H. ve Lee, T. J. (2011). Foreign Travelers' Satisfaction with Traditional Korean Restaurants, International Journal of Hospitality Management, 30: 982-989.

Ottenbacher, M. ve Harrington, R. J. (2009). The Product Innovation Process of Quick-Service Restaurant Chains, International Journal of Contemporary Hospitality Management, 21 (5): 523-541.

Özdemir, B. (2010). Dışarıda Yemek Yeme Olgusu: Kuramsal Bir Model Önerisi, Anatolia: Turizm Araştırmaları Dergisi, 21 (2): 218-232.

Özdemir, B. ve Çalışkan, O. (2011). Otel Dıșı Yemek Deneyimi. İçinde İ. Pırnar, O. İçöz, ve O. Çulha (Editörler). Uluslararası Turizm İşletmeciliği. (ss.475-496). Ankara: Nobel Akademik Yayıncılık.

Özdemir B., Çizel B. ve Çizel R. (2012a). Satisfaction with AllInclusive Tourism Resorts: The Effects of Satisfaction with Destination And Destination Loyalty, Internatio- nal Journal of Hospitality \& Tourism Administration, 13: 109-130.

Özdemir, B., Aksu, A., Ehtiyar, R., Çizel, B., Çizel, R. B. ve İçigen, E. T. (2012b). Relationships Among Tourist Profile, Satisfaction and Destination Loyalty: Examining Empirical Evidences in Antalya Region of Turkey, Journal of Hospitality Marketing \& Management, 21: 506-540.

Özdemir, B., Yılmaz, G., Çalışkan, O. ve Aydın, A. (2015). Şeflerin Yerel Yiyeceğe İlişkin Algılamaları ile Yerel Yiyecek Satın Alma Niyetleri Arasındaki İlişki. 16. Ulusal Turizm Kongresi. (ss. 418-437). Çanakkale: Çanakkale 18 Mart Üniversitesi Turizm Fakültesi.

Quan, S. ve Wang, N. (2004). Towards A Structural Model of The Tourist Experience: An Illustration from Food Experiences in Tourism, Tourism Management, 25: 297-305.

Sharma, A., Moon, J. ve Strohbehn, C. (2014). Restaurant's Decision to Purchase Local Foods: Influence of Value Chain Activities, International Journal of Hospitality Management, 29: 130-143.

Strauss, A. ve Corbin, J. (1990). Basics of Qualitative Research: Grounded Theory Procedurs and Techniques. California: Sage Yayınları.

Şahin, S. (2013). Turistlerin Kırsal Turizme Katılma Nedenleri: Kapadokya'ya Gelen Turistlere Yönelik Bir Araştırma. 14. Ulusal Turizm Kongresi. (ss. 775-797). Kayseri: Erciyes Üniversitesi Turizm Fakültesi.

Üner, E. H. (2014). Her Şey Dahil Sistemde Türkiye Gastronomi Turizmi Potansiyelinin Değerlendirilmesi (Basılmamış Yüksek Lisans Tezi). Ankara: Atılım Üniversitesi Sosyal Bilimler Enstitüsü Turizm Yönetimi Anabilim Dalı

Vujicic, S., Getz, D. ve Robinson, R. (2013). Food Tourists: Who Are They, What Do They Want, How Do You Package Offers, And Reach Them?, Göteborg: Experience Consulting $\mathrm{AB}$.

Yıldırım, A. ve Şimşek, H. (2013). Sosyal Bilimlerde Nitel Araştırma Yöntemleri. Ankara: Seçkin Yayıncılık.

Yıldız, B. Ve Kılıç, S. (2016). Kültür Turizmine Katılan Yerli Turistlerin Kapadokya Algisının Tekrar Ziyaret Etme ve Tavsiye Etme Davranışı Üzerindeki Etkisi, Akademik Bakış Dergisi, 53: 166-185.

Y1lmaz, G. ve Özdemir, B. (2015). Yerel Gastronominin Tan1tım Materyallerindeki Yeri: Kapadokya Bölgesi Üzerine Bir Araștırma. I. Avrasya Uluslararası Turizm Kongresi, (ss.760-780). Konya: Selçuk Üniversitesi Turizm Fakültesi

Yüksel, A. ve Yüksel, F. (2002). Measurement of Tourist Satisfaction with Restaurant Services: A Segment-Based Approach, Journal of Vacation Marketing, 9 (1): 52-68.

Yun, D., Hennessey, S. M. ve MacDonald, R. (2011). Understanding Culinary Tourists: Segmentations Based on Past Culinary Experiences and Attitudes toward FoodRelated Behaviour. International Council on Hotel, Restaurant and Institutional Education (CHRIE) Conference. (ss. 1-13). Colorado: Massachusetts Üniversitesi. 

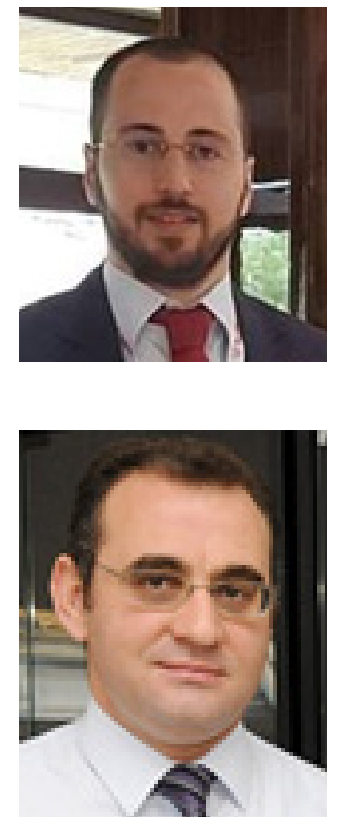

\section{Gökhan YILMAZ}

Erciyes Üniversitesi Nevşehir Turizm İșletmeciliği ve Otelcilik Yüksekokulu Turizm Iş̧letmeciliği ve Otelcilik Bölümü'nden mezun oldu (2010). Yüksek lisans derecesini Akdeniz Üniversitesi Sosyal Bilimler Enstitüsü Turizm İşletmeciliği ve Otelcilik Anabilim Dalı'ndan aldı (2015). Akdeniz Üniversitesi SBE Turizm İşletmeciliği ve Otelcilik Anabilim Dalı'nda doktora eğitimine devam etmektedir. 2010-2012 yılları arasında Adıyaman Üniversitesi'nde Araştırma Görevlisi olarak çalıştı. Halen Akdeniz Üniversitesi Turizm Fakültesi'nde Araştırma Görevlisi olarak görev yapmaktadır. Temel çalışma alanları; Gastronomi ve Mutfak Sanatları ve Yiyecek İçecek Isşletmeciliği'dir.

\section{Bahattin ÖZDEMiR}

Mersin Üniversitesi Turizm İşletmeciliği ve Otelcilik Yüksekokulu Turizm İşletmeciliği ve Otelcilik Bölümü'nden mezun oldu (1999). Yüksek lisans derecesini Akdeniz Üniversitesi Sosyal Bilimler Enstitüsü Turizm İşletmeciliği ve Otelcilik Anabilim Dalı'ndan (2001), doktora derecesini de Akdeniz Üniversitesi SBE İşletme Anabilim Dalı'ndan aldı (2006). Akdeniz Üniversitesi Turizm İșletmeciliği ve Otelcilik Yüksekokulu'nda araştırma görevlisi olarak çalışmaya başladı (1999). Doçentlik unvanını yönetim ve strateji alanında aldı (2011). Profesörlük kadrosuna 2017 yılında atandı. Halen Akdeniz Üniversitesi Turizm Fakültesi'nde görev yapmaktadır. Temel çalışma alanları; yiyecek-içecek işletmeciliği ve gastronomidir. 